\title{
Effects of Different Levels of NPK and Sulphur on Growth and Yield Attributes of Mustard (Brassica juncea L.) Cv. Varuna
}

\author{
Soman Singh Dhruw*, Narendra Swaroop, Akash Swamy and Yogesh Upadhayay \\ Department of Soil Science, Sam Higginbottom Institute of Agriculture, Technology and \\ Sciences, Allahabad, 211007, India \\ *Corresponding author
}

\section{A B S T R A C T}

The field experiment was carried out at Research field of Department of Soil Science, Allahabad school of Agriculture, during rabi season of 2014-15. The experiment was laid out in $3 \times 3$ factorial randomized block design with 9 treatments in three replications. It was observed that the best yield attributes characters in treatment $T_{8-} @ 120: 60: 40 \mathrm{~kg} \mathrm{NPK} \mathrm{ha}^{-1}$

\section{Keywords}

NPK, Sulphur, Growth, Yield, Mustard.

\section{Article Info}

Accepted:

14 June 2017

Available Online:

10 August 2017
$+40 \mathrm{~kg}$ Sulphur ha ${ }^{-1}$ ) in respect to different days intervals i.e. 30, 60, 90 and 120 days after sowing (DAS). Plant height was 20.61, 122.45, 169.67 and $171.91 \mathrm{~cm}$ found to be significant at 120 DAS but non-significant at 30,60 and 90 DAS. Number of leaves plant ${ }^{-1}$ were $8.00,14.22,17.56$ and 8.30 found to be non-significant at 60 and 90 DAS but significant at 30 and 120 DAS. Number of branches plant ${ }^{-1}$ was $9.33,11.44$ and 11.94 found to be significant at 120 but non-significant at 60 and 90 DAS. Highest number of siliqua plant ${ }^{-1}$, Number of seeds siliqua ${ }^{-1}$, fresh weight plant $^{-1}(\mathrm{~g})$, dry weight plant $^{-1}(\mathrm{~g})$, test weight $(\mathrm{g})$, seed yield $\left(\mathrm{t} \mathrm{ha}^{-1}\right)$, straw yield $\left(\mathrm{t} \mathrm{ha}^{-1}\right)$ and oil content $(\%)$ was found in $\mathrm{T}_{8-}$ (@120:60:40 kg NPK ha ${ }^{-1}+40 \mathrm{~kg} \mathrm{Sulphur} \mathrm{ha}^{-1}$ ) which was 301.00, 16.20, 104.44, 37.45, 3.96, 22.00, 45.12 and 37.67 was found to be significant. Highest B: C ratio (1:2.36) was recorded in $\mathrm{T}_{3}-\left(@ 60: 30: 20 \mathrm{~kg} \mathrm{NPK} \mathrm{ha}^{-1}+0 \mathrm{~kg} \mathrm{Sulphur} \mathrm{ha}^{-1}\right)$. However, since these findings are based on one year experiment and therefore, further research may be conducted to substantiate it under Allahabad agro climatic conditions.

\section{Introduction}

Indian mustard (Brassica juncea L.) commonly known as raya, rai or lahi is an important oilseed crop among the Brassica group of oilseed in India. It's the second most important edible oilseed crop in India after groundnut and accounts for nearly $30 \%$ of the total oilseeds produced in the country. Rapeseed-mustard is an important group of edible oil seed crops and contributes around $26.1 \%$ of the total oil seed production and contributes about $85 \%$ of the total rapeseedmustard produced in India (Meena et al.,
2011). The first position in area and second position in Production after China (Anonymous, 2009).

Nitrogen is the most important nutrient, which determines the growth of the mustard crop and increases the amount of protein and the yield. Phosphorus and potash are known to be efficiently utilized in the presence of nitrogen. It promotes flowering, setting of siliqua and in increase the size of siliqua and yield. Sulphur is also an important nutrient and 
plays an important role in physiological functions like synthesis of cystein, methionine, chlorophyll and oil content of oil seed crops. It is also responsible for synthesis of certain vitamins ( $\mathrm{B}$, biotin and thiamine), metabolism of carbohydrates, proteins and oil formation of flavored compounds in crucifers. Brassica has the highest sulphur requirement owing to the presence of sulphur rich glucosinolates (Bharose et al., 2010).

Phosphorus is an element for Toria and mustard. Several scientists of the world have reported that the Toria gives significant response of added phosphorus deficient soils. Phosphorus is generally deficient in majority of our Indian soils and need much attention for maintenance of soil fertility. Several experiments have been conducted under varying agro-climatic conditions by research of different countries. They have reported that phosphorus application in general had beneficial Effect in imparting plant vagour and resistance of plants, against insect pest and disease, and increasing the vegetative growth and seed yield of Toria and mustard. When Phosphorus was applied in conjunction with nitrogen and potash, there was significant increase in the yield of Toria and mustard.

Potassium is one of the seventeen elements which are essential for growth and development of plants. It's for improving the yield and quality of different crops because of its effect on photosynthesis, water use efficiency and plant tolerance to diseases, drought and cold as well for making the balance between protein and carbohydrates (Singh et al., 2010). Sulphur plays the key role is most important among the secondary nutrient in the production of oilseed crops. It plays significant role in the development of seed. An oilseed crop requires sulphur comparatively higher than other nutrient and it is now being recognized as the fourth major element of the plant. Primary nutrient of plants are nitrogen, phosphorus and potassium. Phosphorus plays a vital role in photosynthesis, respiration, cell conclusion cell enlargement and several other processes in living plants. Average over a large amount of data the application of sulphur increased crop yield by $17 \%$ in rice $25 \%$ in soybean $20 \%$ in sunflower and $16 \%$ in linseed (Anonymous, 2011).

The oil content of the yellow mustard seeds ranges from $31-37 \%$ and $20-40 \%$ protein. The seed and oil are used as condiments in the preparation of pickles and for flavoring curries and vegetables. The oil cake is mostly used as a cattle feed and the leaves of young plants are used as green vegetables. The use of mustard oil for industrial purposes is rather limited on account of its high cost. Apart from this yellow mustard cake is also used as organic manure for the soil.

The crop requires relatively cool temperate, a fair sunny and moist weather during the growing period and dry weather during harvest period. Above all the major drawback in the low yield is that is generally grown as a mixed crop potato, sugarcane and gram without the additional application of essential plant nutrient like nitrogen, phosphorus, potash and sulphur.

The main objective is to study the response of NPK and Sulphur application on the yield of Mustard.

\section{Materials and Methods}

The experiment was conducted during rabi season of 2014-15 at Crop research farm Department of Soil Science Allahabad School of Agriculture SHIATS Allahabad. The experimental site is located in the sub tropical region with $25^{0} 27^{1} \mathrm{~N}$ latitude $81^{0} 51^{1}$ $\mathrm{E}$ longitudes and 98 meter the sea level 
altitudes. The experiment was laid out in a $3 \times 3$ RBD factorial design with three levels of NPK and Sulphur with nine treatments, each consisting of three replicates. The total number of plots was 27. Mustard (Brassica juncea L.) were sown in rabi season plots of size $2 \times 2 \mathrm{~m}$ with row spacing $40 \mathrm{~cm}$ and plant to plant distance $15 \mathrm{~cm}$. The Soil of experimental area falls in order of inceptisol. The soil of the experimental field is alluvial in nature, both the mechanical and chemical analysis of soil was done before the starting the experiment to ascertain the initial fertility of the soil. The soil samples were randomly collected from $0-15 \mathrm{~cm}$ depths at randomly prior to tillage operations. The samples were mixed depth viz. and its weight was reducing by air drying, conning, quartering and passing it through $2 \mathrm{~mm}$ sieve. To obtain composite soil sample in respective to different depth viz. the soil was stored for mechanical chemical analyzed. The treatment consisted of nine combination of inorganic source of fertilizers $\mathrm{T}_{0-}\left(@\right.$ 0:0:0 kg NPK ha ${ }^{-1}+0 \mathrm{~kg}$ Sulphur ha $\left.{ }^{-1}\right), \mathrm{T}_{1-}\left(@\right.$ 0:0:0 kg NPK ha ${ }^{-1}+20$ kg Sulphur ha ${ }^{-1}$ ), T 2 (@ 0:0:0 kg NPK ha ${ }^{-1}+$ 40 kg Sulphur ha $\left.{ }^{-1}\right), T_{3-}($ 60:40:20 kg NPK $\mathrm{ha}^{-1}+0 \mathrm{~kg}$ Sulphur ha $\left.{ }^{-1}\right), \mathrm{T}_{4}(@ 60: 30: 20 \mathrm{~kg}$ NPK ha ${ }^{-1}+20 \mathrm{~kg}$ Sulphur ha $\left.{ }^{-1}\right), \mathrm{T}_{5}$ (@60:30:20 kg NPK ha ${ }^{-1}+40 \mathrm{~kg} \mathrm{Sulphur} \mathrm{ha}^{-1}$ ), T6-(@120:60:40 kg NPK ha ${ }^{-1}+0$ kg Sulphur $\left.\mathrm{ha}^{-1}\right), \mathrm{T}_{7-}\left(@ 120: 60: 40 \mathrm{~kg}\right.$ NPK ha ${ }^{-1}+20 \mathrm{~kg}$ Sulphur ha $\left.{ }^{-1}\right), \mathrm{T}_{8}$ - @120:60:40 kg NPK ha ${ }^{-1}+$ $40 \mathrm{~kg}$ Sulphur $\mathrm{ha}^{-1}$ ). The source of NPK and Sulphur Urea, DAP, MOP and Zinc sulphate respectively.

Physical and chemical analysis of soil samples (pre-sowing)

\section{Results and Discussion}

\section{Growth parameters}

Table 2 shows the interaction effect of different levels of NPK and Sulphur in the important growth parameters of mustard crop.

\section{Plant height (cm)}

Increase in plant height due to increasing of NPK and Sulphur may be due to adequate nutrients which are turns help in vigorous vegetative growth of plants and subsequently increase the plant height through cell elongation cell division photosynthesis and turbidity of plant cell. The maximum height recorded as 20.61, 122.45, 169.67 and 171.91 respectively at 30,60, 90 and 120 DAS in treatment $\mathrm{T}_{8}$. Similar results have also been recorded by Tripathi et al., (2011).

Table.1 Physical analysis of soil

\begin{tabular}{llc}
\hline Particulars & Method employed & Results \\
\hline Sand $(\%)$ & Bouyoucous Hydrometer & 60.00 \\
Silt $(\%)$ & method Bouyoucous (1927) & 20.12 \\
Clay $(\%)$ & & 19.88 \\
Textural class & Core method & Sandy loam \\
Bulk density $\left(\mathrm{g} \mathrm{cm}^{-3}\right)$ & Graduated measuring cylinder Black (1965) & 1.30 \\
Particle density $\left(\mathrm{g} \mathrm{cm}^{-3}\right)$ & Graduated measuring cylinder Black (1965) & 2.47 \\
Pore Space $(\%)$ & Graduated measuring cylinder Black (1965) & 56.95 \\
\hline
\end{tabular}


Table. 2 Shows the interaction effect of different levels of NPK and Sulphur the important growth parameters of mustard crop

\begin{tabular}{|c|c|c|c|c|c|c|c|c|c|c|c|}
\hline \multirow[t]{2}{*}{ Treatment } & \multicolumn{4}{|c|}{ Plant height (cm) } & \multicolumn{4}{|c|}{ Number of leaves plant ${ }^{-1}$} & \multicolumn{3}{|c|}{$\begin{array}{l}\text { Number of branches } \\
\text { plant }^{-1}\end{array}$} \\
\hline & 30 DAS & 60 DAS & 90 DAS & $\begin{array}{l}120 \\
\text { DAS }\end{array}$ & 30 DAS & 60 DAS & 90 DAS & $\begin{array}{c}120 \\
\text { DAS }\end{array}$ & 60 DAS & 90 DAS & $\begin{array}{c}\text { 120 } \\
\text { DAS }\end{array}$ \\
\hline $\mathbf{T}_{0}$ & 14.14 & 64.6 & 103.44 & 105.32 & 5.78 & 11 & 13.56 & 5.3 & 6.33 & 7.78 & 8.28 \\
\hline $\mathbf{T}_{1}$ & 15.22 & 79.44 & 117.44 & 118.5 & 6.33 & 11.33 & 14.22 & 5.5 & 6.66 & 8.44 & 8.94 \\
\hline $\mathbf{T}_{2}$ & 15.09 & 81.11 & 119 & 121 & 6.67 & 12 & 15.11 & 5.63 & 7.67 & 9.22 & 9.72 \\
\hline $\mathbf{T}_{3}$ & 15.85 & 92.66 & 139.44 & 140.72 & 6.67 & 11.89 & 15.67 & 5.73 & 7.87 & 9.22 & 9.72 \\
\hline $\mathbf{T}_{4}$ & 16.52 & 100.33 & 151.33 & 153.39 & 6.78 & 11.89 & 15.89 & 6.2 & 8.33 & 9.56 & 10.06 \\
\hline $\mathbf{T}_{5}$ & 17.29 & 104.66 & 156.78 & 158.16 & 6.89 & 13.22 & 16.11 & 6.87 & 8.44 & 10.56 & 11.06 \\
\hline$T_{6}$ & 16.33 & 117 & 162.22 & 163 & 7.33 & 13.22 & 16.78 & 6.1 & 8.67 & 10.67 & 11.17 \\
\hline $\mathbf{T}_{7}$ & 17.97 & 122.33 & 166.22 & 167.89 & 7.44 & 14.22 & 17.11 & 7.17 & 9.11 & 10.78 & 11.28 \\
\hline $\mathbf{T}_{8}$ & 20.61 & 122.44 & 169.67 & 171.91 & 8 & 14.22 & 17.56 & 8.3 & 9.33 & 11.44 & 11.94 \\
\hline F-test & $\mathrm{NS}$ & $\mathrm{NS}$ & $\mathrm{NS}$ & $\mathrm{S}$ & $S$ & NS & NS & $S$ & $\mathrm{NS}$ & $\mathrm{NS}$ & $\mathrm{S}$ \\
\hline S.Ed. $( \pm)$ & 1.424 & 5.857 & 6.809 & 1.978 & 0.175 & 0.359 & 0.314 & 0.108 & 0.249 & 0.265 & 0.155 \\
\hline $\begin{array}{c}\text { C.D. (at } \\
5 \%)\end{array}$ & 3.02 & 12.417 & 14.435 & 4.193 & 370 & 0.76 & 0.665 & 0.229 & 0.528 & 0.562 & 0.329 \\
\hline
\end{tabular}


Int.J.Curr.Microbiol.App.Sci (2017) 6(8): 1089-1098

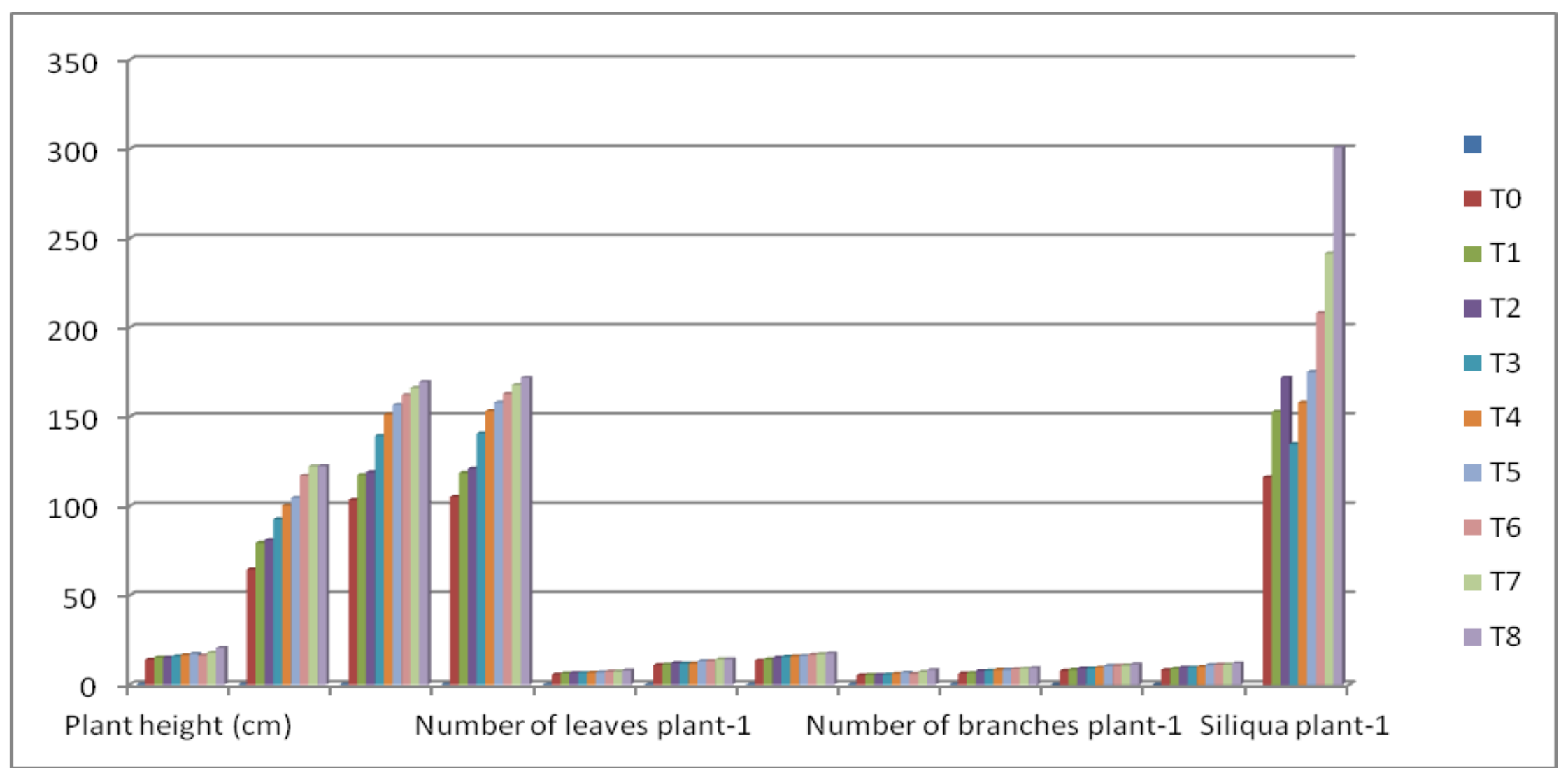


Table.3 Shows the interaction effect of different levels of NPK and Sulphur the important plant yield attributes parameters of mustard crop

\begin{tabular}{|c|c|c|c|c|c|c|c|c|c|}
\hline Treatment & $\begin{array}{l}\text { Siliqua } \\
\text { plant }^{-1}\end{array}$ & $\begin{array}{l}\text { Seeds } \\
\text { siliqua }^{-1}\end{array}$ & $\begin{array}{l}\text { Fresh } \\
\text { weight }(g)\end{array}$ & $\begin{array}{l}\text { Dry } \\
\text { weight }(g)\end{array}$ & $\begin{array}{l}\text { Test } \\
\text { weight } \\
\text { (g/1000 } \\
\text { seeds) } \\
\end{array}$ & $\begin{array}{l}\text { Total } \\
\text { grain yield } \\
\left(\mathrm{t} \mathrm{ha}^{-1}\right)\end{array}$ & $\begin{array}{l}\text { Stover } \\
\text { yield (t ha- } \\
\mathbf{1}_{\text {) }}\end{array}$ & $\begin{array}{l}\text { Oil content } \\
(\%)\end{array}$ & $\begin{array}{l}\text { B:C } \\
\text { Ratio }\end{array}$ \\
\hline $\mathbf{T}_{\mathbf{0}}$ & 116.12 & 14.40 & 15.78 & 4.89 & 3.78 & 1.36 & 2.83 & 29.87 & 1.93 \\
\hline $\mathbf{T}_{1}$ & 152.90 & 14.40 & 21.78 & 7.00 & 3.79 & 1.43 & 2.97 & 31.03 & 1.88 \\
\hline $\mathbf{T}_{2}$ & 172.01 & 14.50 & 30.11 & 9.55 & 3.85 & 1.55 & 3.22 & 32.80 & 1.89 \\
\hline $\mathbf{T}_{3}$ & 134.80 & 15.10 & 46.67 & 13.11 & 3.86 & 1.86 & 3.84 & 32.53 & 2.36 \\
\hline $\mathbf{T}_{4}$ & 158.00 & 15.20 & 65.89 & 19.67 & 3.88 & 1.98 & 4.07 & 34.17 & 2.33 \\
\hline $\mathbf{T}_{5}$ & 175.23 & 16.10 & 76.56 & 23.11 & 3.90 & 2.08 & 4.27 & 34.93 & 2.29 \\
\hline$T_{6}$ & 208.22 & 15.30 & 90.11 & 30.56 & 3.93 & 2.00 & 4.12 & 35.53 & 2.28 \\
\hline $\mathbf{T}_{7}$ & 241.56 & 16.30 & 96.22 & 33.21 & 3.95 & 2.12 & 4.35 & 36.50 & 2.26 \\
\hline $\mathbf{T}_{8}$ & 301.00 & 16.20 & 104.44 & 37.45 & 3.96 & 2.20 & 4.51 & 37.67 & 2.21 \\
\hline F-test & NS & $\mathrm{S}$ & $\mathrm{S}$ & $\mathrm{S}$ & $\mathrm{S}$ & $\mathrm{S}$ & $\mathrm{S}$ & $\mathrm{S}$ & \\
\hline S.Ed. ( \pm$)$ & 27.362 & 1.015 & 2.826 & 1.028 & 0.006 & 0.094 & 0.189 & 0.181 & \\
\hline $\begin{array}{c}\text { C.D. (at } \\
5 \%)\end{array}$ & 58.007 & 2.152 & 5.990 & 2.179 & 0.013 & 0.200 & 0.400 & 0.384 & \\
\hline
\end{tabular}




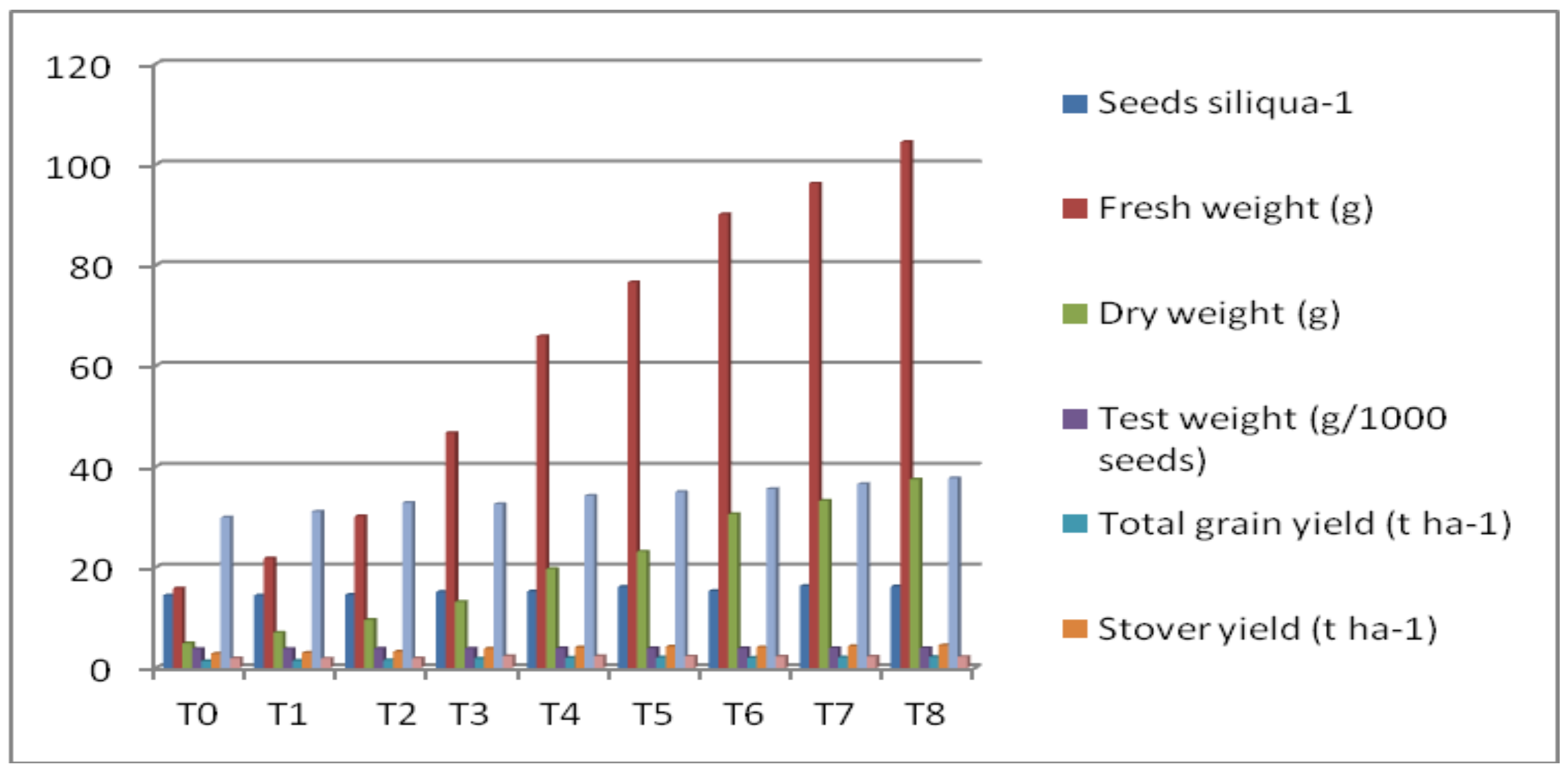


Table.4 Chemical analysis of soil

\begin{tabular}{lll}
\hline Particulars & Method employed & Results \\
\hline pH (1:2) & $\begin{array}{l}\text { Digital pH meter } \\
\text { (Jackson, 1958) }\end{array}$ & 7.27 \\
EC $\left(\mathrm{dSm}^{-1}\right)$ & $\begin{array}{l}\text { EC meter (Digital Conductivity Meter) } \\
\text { (Wilcox, 1950) }\end{array}$ & 0.28 \\
$\begin{array}{l}\text { Organic Carbon (\%) } \\
\text { Available Nitrogen }\left(\mathrm{kg} \mathrm{ha}^{-1}\right)\end{array}$ & $\begin{array}{l}\text { Alkalkey and Black's method, 1947) } \\
\text { (Subbaih and Asija, 1956) }\end{array}$ & 0.41 \\
Available Phosphorus $\left(\mathrm{kg} \mathrm{ha}^{-1}\right)$ & $\begin{array}{l}\text { Colorimetric method } \\
\text { (Olsen } \text { et al., 1954) }\end{array}$ & 352.08 \\
Available Potassium $\left(\mathrm{kg} \mathrm{ha}^{-1}\right)$ & $\begin{array}{l}\text { Flame photometric method } \\
\text { (Toth and Prince, 1949) }\end{array}$ & 24.78 \\
Available Sulphur $\left(\mathrm{kg} \mathrm{ha}^{-1}\right)$ & $\begin{array}{l}\text { Turbidemetric } \\
\text { (Chesnin and Yien, 1950) }\end{array}$ & 25.83 \\
\hline
\end{tabular}

\section{Number of leaves plant ${ }^{-1}$}

The effect of different levels of NPK and Sulphur on number of leaves plant ${ }^{-1}$ was found significant at 30 , and 120 DAS, whereas found non-significant at 60 and 90 DAS. The maximum number of leaves plant ${ }^{-1}$ was recorded as $8.00,14.22,17.56$ and 8.30 respectively at 30,60, 90 and 120 DAS in treatment $\mathrm{T}_{8}$ Similar results have also been recorded by Tripathi et al., (2011).

\section{Number of branches plant ${ }^{-1}$}

The effect of different levels of NPK and Sulphur on number of branches plant ${ }^{-1}$ was found to be significant at 120 DAS. Whereas found non-significant at 60 and 90 DAS. The maximum number of plant $^{-1}$ was recorded as $9.33,11.44$ and 11.94 respectively at 60,90 and120 in treatment $\mathrm{T}_{8}$ Similar results have also been recorded by Tripathi et al., (2011). Table 3 shows the interaction effect of different levels of NPK and Sulphur the important plant yield attributes parameters of mustard crop. Higher yield response in comparison of NPK and Sulphur alone was recorded with balanced application of NPK and Sulphur. The maximum number of siliqua plant $^{-1}$ was recorded as 301.00 in treatment $T_{8}$ and minimum number of siliqua plant ${ }^{-1}$ was recorded as 116.12 in treatment $\mathrm{T}_{0}$ and were found to be significant. The maximum fresh weight of plant recorded as 104.44 in treatment $T_{8}$ and minimum fresh weight of plant was recorded as 15.78 in treatment $\mathrm{T}_{0}$ were found to be significant, The maximum dry weight of plant was recorded as 37.35 in treatment $\mathrm{T}_{8}$ and minimum dry weight of plant was recorded as 4.89 in treatment $\mathrm{T}_{0}$ and were found to be significant. The maximum test weight of seeds $3.96 \mathrm{~g}$. was recorded in $\mathrm{T}_{8}$ and minimum test weight of seeds was $3.78 \mathrm{~g}$ recorded in $\mathrm{T}_{0}$ and were found to be significant. The maximum seed yield $2.20 \mathrm{t}$ $\mathrm{ha}^{-1}$ was recorded in $\mathrm{T}_{8}$ and minimum seed yield $1.36 \mathrm{t} \mathrm{ha}^{-1}$ was recorded in $\mathrm{T}_{0}$ and were found to be significant. The maximum stover yield $4.51 \mathrm{t} \mathrm{ha}^{-1}$ was recorded in $\mathrm{T}_{8}$ and minimum stover yield $2.83 \mathrm{t} \mathrm{ha}^{-1}$ was recorded in $\mathrm{T}_{0}$ which were found to be nonsignificant. Among the different treatments studied with respect of maximum Oil Content in seeds (\%), The maximum Oil Content in seeds (\%) was recorded in $\mathrm{T}_{8}$ (37.67) and the minimum was recorded $\mathrm{T}_{0}$ (29.87). 
It is concluded that the best yield attributes characters in treatment $\mathrm{T}_{8}$ in respect to different days intervals i.e. 30,60,90 and 120 days after sowing (DAS). Plant height was $20.61,122.44,169.67$ and $171.91 \mathrm{~cm}$ found to be significant at 120 DAS but non-significant at 30,60 and 90 DAS, number of leaves plant ${ }^{-1}$ were $8.00,14.22,17.56$ and 8.30 found to be significant at 30 and 120 DAS but nonsignificant at 60, and 90 DAS, number of branches plant ${ }^{-1}$ was 3.33,9.44 and 9.94 found to be at 120 DAS significant and at 60 and 90 DAS non-significant. Highest number of siliqua plant ${ }^{-1}$ was 301.00 found to be nonsignificant. Highest fresh weight(g), dry weight $(g)$, test weight $(g)$, seed yield(t), stover yield(t), and oil content $(\%)$ which was 16.20 , $104.44,37.45,3.96,2.20,4.51,37.67$ found to be significant. $T_{8}$ which was found to be significant. Highest B:C ratio (2.36) was recorded in $\left(\mathrm{T}_{3}\right)$.

\section{Acknowledgements}

The Authors are thankful to Department of Soil Science, SHIATS, Allahabad School of Agriculture, for taking their keep interest and encouragement to carry out the research work.

\section{References}

Anonymous. 2009. Economic survey, Ministry of Finance, Government of India.

Fisher, R.A. 1950. Technique of Analysis of Cviance. Handbook of Agricultural Statistics, B-29- 110.

Gavade, P.G. and Shigvan, K.Y. 2009. Effect of sulphur, potassium and micronutrient complex on yield and free proline accumulation in mustard [Brassica juncea (L.) Czernj and Cosson] cv. 'VARUNA' under water stress condition. Int. J. Plant Sci., Vol. 4: 338340.

Hedge, D.M. 2007. Increasing production
area.In Hindu survey of Indian Agri., 42-43.

Jyoti, K., Nail, S.S., Mandal, M. and Das, D.K. 2012. Performance of different Sources of sulphur on the Yield and Quality of Rapessed (Brassica campestris L.) J. Indian Society of Soil Sci. vol. 60, No.3 pp218-224.

Khan, H., Khan, M.A. and Hussain, I. 2000. Effect of Nitrogen and Phosphorus on Growth and Yield of Brassica juncea L. Pak. J. Biol. Sci., 3(8): 1231-1233.

Khatkar, Y., Dawson, J., Kishanrao, Z.K., Dixit, P.M. and Khatkar, R. 2009. Effect of nitrogen, phosphorus and sulphur fertilization on growth and yield of mustard (Brassica juceae Coss). Int. J. Agri. Sci., Vol. 5: Issue 2: 396-398.

Meena, D.S., Meena, V.R. and Meena, A.K. 2013. Fertilizer management studies on growth and productivity of hybrid Indian mustard Brassica juncea (L.) J. Oilseed Brassica, 4(1): 39-42.

Oad, F.C., Qayyum, S.M., Oad, N.L., Gandahi, A.W., Sohu, G.N. and Chandio, G.Q. 2001. Effect of Various NPK Fertilizer Doses on the Growth, Seed Yield and Oil Content of Brassica. Pak. J. Appl. Sci. 1(3): 337-378.

Ram Bharose, Chandra, S., Thomas, T. and Dhan, D. 2010. Effect of different levels of phosphorus and sulphur on yield and availability of NPK protein and oil content in Tpria. (Brassica sp.) CV. P.T.-303. ARPN J. Agri. Biol. Sci., Vol 6, No 2.

Singh, C., Singh, P. and Rajbir, S. 2010. Oil crops of mustard (Brassica juncea L.) Genaral introduction Modern techniques of raising field crops. Oxford and IBH publishing Company Pvt. Ltd., New Delhi. p.273-291.

Singh, J., Sinhg, N.S.H. and Bhadauria, H.S. 2012. Nitrogen and sulphur requirement of mustard under different crop sequences. Ann. Pl. Soil Res., 14(2): 
113-115.

Meena, D.S., Meena, V.R. and Meena, A.K. 2013. Fertilizer management studies on growth and productivity of hybrid Indian mustard Brassica juncea (L.) $J$. Oilseed Brassica, 4(1): 39-42.

Singh, R., Singh, A.K. and Kumar, P. 2014. Performance of Indian Mustard (Brassica juncia L.) in Response to Integrated Nutrient Management. $J$. Agri. Search, 1(1): 9-12.

Tripathi, M.K., Chaturvedi, S., Shukla, D.K.,
Saini, S.K. 2011. Influence of integrated nutrient management on growth, yield and quality of Indian mustard (Brassica juncea L.) in tarai region of northern India. J. Crop and Weed, 7(2): 104-107. Verma, C.K., Prasad, K. and Yadav, D.D. 2012. Studies on response of sulphur, zinc and boron levels on yield, economics and nutrients uptake of mustard [Brassica juncea (L.) Czern and Coss.]. Crop Res., (Hisar) 44(1/2): 75-78.

\section{How to cite this article:}

Soman Singh Dhruw, Narendra Swaroop, Akash Swamy and Yogesh Upadhayay. 2017. Effects of Different Levels of NPK and Sulphur on Growth and Yield Attributes of Mustard (Brassica juncea L.) Cv. Varuna. Int.J.Curr.Microbiol.App.Sci. 6(8): 1089-1098.

doi: https://doi.org/10.20546/ijcmas.2017.608.135 